\title{
An investigation into the level of empowerment of rural women in the Zululand district of KwaZulu-Natal province of South Africa
}

\author{
BR Bhengu, PhD \\ School of Nursing, Titiversity of KwaZulu-Natal
}

\section{Kev words}

primary health care, rural women, economic development, empowerment, entrepreneurship, community development

\section{Correspondence address}

5th Floor Desmond Clarence Building Howard College Campus

University of KwaZulu-Natal

Durban 4041

\section{Abstract: Curationis 33 (2): 4-12}

The aim of the study was to evaluate the outcome of the empowerment of rural women in relation to gender issues, power, and communication within the Zululand District of KwaZulu-Natal in South Africa after implementation of a four-year Primary Health Care project in partnership with the Provincial Department of Health, and two Schools of Nursing at the University of KwaZulu-Natal and McMaster University in Canada.

This project is based on substantial evidence which reveals that rural women are being neglected to the extent that these women have missed out on opportunities for development. The reasons for this disempowerment of women, particularly rural women, are thought to be due to the feminisation of poverty, as well as female submission, educational deprivation, privacy of domestic violence, exploitation, domination by men and cultural oppression (patriarchy).

A qualitative research approach was used. Focus group discussion was utilised as the data collection technique, and this was also applied during the collection of baseline data. An interview guide covered issues of concern in the communities and households, including what the women would, or had done about these, how they engaged in decision-making in their families, how they handled situations when there was a difference of opinion, and their awareness of, and ability to claim their rights, including control of their lives. The data was collected from six clinics, from groups of six to ten women in the predominantly rural Zululand District of KwaZulu-Natal.

The project has revealed improvement in the women's realisation of their rights, albeit limited, in communication, self-confidence, and reliance, including partnerships between Primary Health Care Nurses and women's groups. The formation of women's groups facilitated community development and participation in their own health, socio-economic and emotional development.

The project suggests that such groups be encouraged and allowed to network for support as they understand their own problems better, they merely require facilitation.

Tel : (031) 260-1134

Fax:(031)260-1543

Email: Bhengub2@ukzn.ac.za 


\section{Introduction}

Mogotlane and Uys (2000:20) contend that community participation leads to community development, which in turn leads to health. To achieve this, most authors propose empowerment of the disempowered/oppressed through transformative education and learning, organisation into income-generating groups, and formation of informal support networks (Oberhauser, 1998: 3; Bridge2001:1; Dugan, 2003:2). Furthermore, MacKian (2008; 107) strongly suggests that women are the best sector of the population to empower and mobilise, because they have the greatest informal influence over the health and wellbeing of the wider community. Rural women are known to possess indigenous knowledge that Olatokun and Ayanbode (2008: 48) suggest must be recognised and encouraged to enhance sustainable development. Murphy-Graham (2010: 321) cites Hartstock (1983: 253) referring to power among women as capacity rather than domination. Capacity, according to this author, culminates in women recognising intrinsic worth, hence beginning to participate on equal terms with men to discard patriarchy, and to promote social and economic development.

Blumberg (2005: 4) believes that empowerment of women, especially economic empowerment, would promote self-confidence and the attainment of a voice in household decisions which are usually taken for domestic well-being, such as equitable regard for sons and daughters, improved diets, survival, education and health. MurphyGraham (2010: 321) suggests that empowerment in terms of gender is characterised by social conditions and relationships that manifest mutuality and co-operation, with both men and women reaching their potential. Syed (2010 :283), however, cautions that socio-cultural and religious contexts should be considered in exploring gender empowerment.

Minister of Finance in (2007), Trevor Manuel is cited by Bohler-Muller and Daniels (2009:26) as suggesting that rural women produce about $80 \%$ of the food growth in Africa, while they own just $2 \%$ of all agricultural land, and only $1 \%$ of agricultural credit. Women in South Africa constitute $52 \%$ of the to- tal population, and almost half, (47\%) of these live in rural areas (Gillwald, 2002:1). Meer, as cited by Kongolo and Bamgose (2002:79) suggests that there is substantial evidence that rural women are neglected and, as a result, miss out on opportunities for development. Reasons for this disempowerment of women, particularly those in rural areas, are thought to be attributed to feminisation of poverty, domination and exploitation, educational deprivation, domestic violence and cultural oppression. Du Plessis (2007: 4) also suggests a lack of infrastructure, safety and security as other challenges to rural women. The emergence of HIV/AIDS, female submission and some cultural practices like the 'sit-in-spouse' for a widow, and the boys' initiation in Malawi (forcing newly-initiated boys to have sex with girls), including the belief that sexual intercourse with virgins can cleanse men infected with HIV/ AIDS, have compounded the problem by leading to the spread of this disease, thus making female subordination a health hazard. HIV infection in younger females aged 15-24 years is, about six times higher than the infection in younger males (Women's International Network cited in Bridge, 2001:8) as a result of this.

A project was launched in the Zululand district in KwaZulu-Natal in 1999 which aimed at improving the participation of rural women in primary health care (PHC). This project sought to enable women in the locality of the clinics and district hospitals to play a more active, positive and informed role in their health and that of their families through the medium of local nurses. Three partners, the Provincial Department of Health, KwaZulu-Natal, the Schools of Nursing of the Universities of KwaZuluNatal, and McMaster in Hamilton (Canada) were involved. Baseline data was collected including, health service utilisation, disease profile, household health practices, knowledge and attitudes of Traditional Birth Attendants towards HIV/AIDS, and the level of empowerment as manifested in the women's verbalisation and actions. It would therefore be of interest to analyse the change in the level of empowerment among the groups of women who participated, post-implementation of this project.

\section{Literature Review}

Historically the status of women has been inferior and subordinate to men. Women started out as valuable economic and social properties, and as perpetual minors contributing to a form of individual gratification and also as status symbols (Reader, 1966:335). It has been observed that studies in history and society avoided issues concerning women, and used males as informants, even on issues pertaining to women, thereby endorsing the 'invisibility' of women (Obbo, 1981:1). Denial of access to education for African women in the majority of Sub-Saharan countries compounds the problem. For example, the average literacy rate in these countries is $49.6 \%$ for women compared to $66 \%$ for men (Kachingwe, 2001c 2002:1). While literature recommends income-generating groups among these women, inadequate training, finance and technological support limits their participation (Oberhauser, 1998:6). This attitude towards women damages their independence and is attributed mainly to bride price (lobola), just as dowry and forced and early (child) marriages also contribute towards dependence.

Economic deprivation is further blamed for compounding the inferior status of women. The African economy has assimilated the values of a western cash economy, which is just 'subsistence economy', whereby the povertystricken rural communities work to earn money in cash, just to survive. These communities thus need to reduce their material wants to a bare minimum (Reader, 1966:332). Economic deprivation is also seen in the labour markets where women are concentrated in lowpaid and vulnerable jobs such as casual agricultural labour, domestic work and in the informal sector. Rural women, in particular, have little spare time (due to heavy workloads) to take advantage of livelihood/sustenance opportunities. There is also a high rate of femaleheaded households, especially of black African women with men having engaged in migrant labour in cities (Oberhauser, 1998:4;Bridge 2001:1). Yet Akinsola, and Popovich (2002 762) argue that there is a link between femaleheaded households and poverty, though Waite (2000 155) cautions that such households could also be inter- 
preted as those in which women have rejected patriarchal constraints by opting out of nuclear families. As a result, women live in fear and vulnerability, which is worsened by the increasing level of violence in the schools, workplace and homes, for example, rape, thought to be due to male domination in these institutions and regard for domestic violence as a private matter which should not be disclosed to outsiders therefore do not speak about it nor seek assistance (Locke, 1999:1; Kachingwe, 2001:2). Women are denied access to the political realms. Moreover, most victims of abuse think that there is no authority that protects them, and that punitive measures are not harsh enough for the degree of the offence (Kachingwe, 2001:2).

South Africa has a vision for a human rights-based society which brings women's issues to the fore (Gillwald, 2002:2). The South African constitution guarantees equality, and the law upholds this principle (RSA Constitution, Act 108 of 1996), however, there is a gap between this and what is actually happening, and this is particularly prevalent in the rural communities. International conventions committed to the empowerment of women have increased namely, The Mexico Plan of Action, 1975; Nairobi Forward-Looking Strategies (1985); The Convention on Elimination of all forms of Discrimination against Women (CEDAW) in 1993; The Beijing Declaration and Platform of Action in 1995, etc. (National Policy for the Empowerment of Women, India, 2001). A conscious effort was therefore made by the South African government and the private sector to open some positions to women in South Africa, however, this predominantly affected urban women (Commission on Gender Equality, 2009: 1-3; RSA Constitution, Act No 108 of 1996: 99).

\section{Programme Description}

The University of KwaZulu-Natal, together with MacMaster University in Canada chose to empower rural women to claim their rights, and to participate in decision-making within the scope of the Primary Health Care principles and the South African constitution. The empowerment project included three modules: one on economic, justice and political enlightenment, a second on health and health promotion, and the third on education, gender issues, power and change, including communication. The project started with the training of nurses from Primary Health Clinics to run empowerment groups for women in their areas, and to work through a formal curriculum with them. The training of nurses took only two days and focused mainly on the philosophy and methods of peer, or adult teaching, involving learners in learning and health promotion. The nurses each received a teaching guide setting out the content to be taught and the methods to be followed for each topic. They also received a flip-chart of visual aids around which to introduce topics and discussions.

The PHC nurses were then tasked with running such empowerment groups for women around their clinics. The curriculum covered human rights, domestic violence and how to deal with it, how to access social assistance, the promotion of good education for children, the promotion of health of self and family, caring for a family member who is ill and income generation.

\section{Empowerment: A Conceptual Analysis}

The term "empowerment" as used in this project was based on the argument by Van de Merwe (1996:26) that empowerment cannot take place unless the person or group is aware of their own powerlessness, is unhappy about it, and is willing to become engaged with change. The steps in the process of empowerment were based on those suggested by Vlasoff(2001:2), namely:

- To build equality at home, to teach children to be equals as brothers and sisters.

- To organise women into groups, giving them the opportunity to talk, share knowledge, gain confidence and make decisions more binding.

- To assist with non-formal education and training, including adult basic education and literacy programmes.

- To incorporate skills development in all aspects of the community life of women. (These skills included interpersonal skills such as assertiveness and conflict resolution which were seen to enable women to deal with many household and community problems)

The following indicators of empowerment as proposed by Phillip and Bhargava cited in Uys and Majumdar (2000) were used to evaluate the project:

- Individual: The person feels a sense of power

- Interpersonal: The person shows the ability to affect others

- Organisational: The person or organisation has the organising ability to empower individuals and communities

- Political: the person or organisation demonstrates the ability to work with others to change social institutions

\section{The purpose of the Study}

The purpose of this study was to evaluate the outcome of the empowerment programme in relation to gender issues, power, and communication among women within the Zululand District of KwaZulu-Natal.

\section{The objectives of the Study}

The objectives of the project were to survey the power issues of rural women in relation to:

- Power-sharing in families, communities and other institutions

- Communication within the families and communities

- Claiming of human rights

- $\quad$ Self-reliance, including

- Support services for empowerment

\section{Setting}

The data was collected from six clinics in the Zululand District of KwaZuluNatal, which is predominantly rural. Not all the clinics participated, as per the experimental and control clinic selection as was initially intended, but according to whether the clinics were funded. This funding was provided for income generation by groups of women that were formed in collaboration with the clinics, and co-ordinated by the 
clinic staff. These groups had to apply for funding which was administered by the University of KwaZulu-Natal. The group of women were taught how to conduct business including the writing of business plans, banking, etc., however, as far as possible, the experimental and control clinics were included as follows:

\section{- 2 Funded clinics}

- 2 Clinics that were not funded but applied

- 2 Clinics that fell by the wayside

\section{Methodology}

A qualitative research approach was used. Focus group discussion was utilised as the data collection technique, and this was also applied during the collection of baseline data on the level of power. This would enable the researchers to compare the baseline data with this study data and determine the change in the level of power. Focus group discussion allows a number of women to be included at one time, making this form of data collection more economical, flexible, stimulating, cumulative, elaborative and assist in information recall (Fontana \& Frey, 1994 cited in Speziale \& Carpenter, 2007:38). Pini (2002: 341) argues that focus groups provide an opportunity for research that is consciousness raising and empowering, with the group interaction allowing for "power relationships to be more greatly diffused, knowledge to be collectively constructed, and empowerment, as participants challenge, question, critique and learn from each other". This author further suggests that focus groups obviate the hierarchical research relationship and produce knowledge about women's lives in context. The majority of women were also illiterate, therefore a written form of data collection would not have been possible. Each group was composed of six to ten women, with two groups containing male members by choice. One focus group was held with each group. The interview guide covered issues in their communities and households that the women were not happy with, or regarded as problems, including what they would do or had done about them. The women were also asked how they engaged in decision-making in their families, including how they handled situations when there was a difference of opinion. They were also questioned about awareness of, and ability to claim their rights, including control of their lives.

\section{Credibility}

To ensure credibility of the methodology, the interviews were held at the clinics close to their homes, where the women were trained, which ensured a naturalistic context. The interviews were conducted in Zulu, tape-recorded with permission, transcribed into Zulu and translated into English. The transcripts were cross-checked with the research assistant who also analysed some of the transcripts to establish the consistency of the themes which emerged.

\section{Focus Group Trigger Questions}

1.1. How do you respond to any issue in your community (schools, clinic, church) that you are unhappy about? 12. What is it that you do to change this situation?

2.1. How do you respond to unhappy issues/situations in your family?

2.2. What do you do to change this?

3.1. How are decisions made in your house about:

- How money is spent?

- How children are raised?

- Where to live, visit, or to work?

4. When there are differences of opinion in your family, how are they handled?

5. To what extent have you got control over your own life, and the things that matter to you?

6. Rights:

- What are the rights that you think you have?

- What are the rights that you think you don't have?

- How do your rights differ from the man's rights if there is any difference?

- What are the things/who are the people who may be, or are taking your rights away?

- What are things or who are the people who are negatively influencing your rights?

\section{Data Analysis}

Data from the focus group discussions were analysed using the open coding method according to Tesch's eight steps cited in (Creswell 2009 :186). Similar data or ideas were clustered into themes which emerged as meaningful units indicating change, or no change in the level of power.

\section{Discussion of findings}

Eight themes emerged, as discussed hereunder.

\section{Group cohesion enforced}

The formation of women's groups engendered a climate of sharing and support amongst these women. They learned to trust each other, and began to share their problems and solve them together. These groups acted as outlets, and allowed for catharsis when a woman had problems especially with her family. For example, the women quoted an incident when one woman discussed the family problem of an alcoholic husband. The women counseled her on how to cope and encouraged her to persevere but "we could not talk to the husband directly". The women also acknowledged the need to refer these women when necessary, but felt they had, so far, been able to give advice without referral.

\section{Acting as resource people}

The women's groups enabled these women to assist others in the community with their problems and concerns. They were able to educate and advise women in the community and so disseminated some of their recently-acquired power. Women within and outside the groups would consult the women's groups about their own family problems and community problems. For example:

- $\quad$ First aid for sick members of the community. One woman quoted an incident when she successfully treated a child with fever by tepid sponging before sending it to hospital. "I was called by a neighbour for a child who was hot, and I gave it a warm bath. It got better".

- $\quad$ Health advice about the care and attitude towards community members who live with HIV/AIDS was also quoted by several groups. For example, one group quoted an incident when they visited a family after 
having heard how the family had ostracised a family member who was living with HIV/AIDS. The women visited the family and informed them as to how the illness is spread, and urged the family to take care of the sick member and not reject her.

Economic advice was also given. For example, three groups quoted incidents when they were requested by other groups that were trying to form their own groups locally to provide information on "forming groups, writing a constitution and opening a bank account".

Some women quoted an incident where a man who had been a migrant labourer had died away from home, in Johannesburg. The women were able to advise the family about the importance of getting a death certificate to be able to obtain support for the orphans.

\section{Communication improved}

The groups learned to know one another better and came to trust one another. They shared pleasures and problems together. Communication did not just improve among the women themselves, but also within the wider community, hence they were consultants in relation to health and economic development. Of note was also the communication between the women's groups and the clinic staff members. This was observed by the researchers in all clinics which were visited for the focus group discussions. The women were able to use some facilities in the clinic for their projects, like unused land for gardening, and empty rooms at the staff residence. In one clinic, a general assistant was absent and there was no relief staff member available to clean. One of the women was already cleaning the floors when the researchers arrived.

\section{Improved survival economy}

Women had small businesses which were sponsored by the empowerment project. The sponsorship was earned by presenting business plans which were reviewed by the project members. Even those groups that were not sponsored had gardens and chickens which they kept, and handwork, which they survived on. All groups did not make significant income from their projects, but they were all surviving. Even the most remote clinic which fell by the wayside, quoted projects which they had undertaken on their own, for example, sewing school uniforms, but because they were not an organised group, they could not earn anything from these uniforms. They could not even track what happened to their project after these uniforms were submitted to the school.

\section{Self-reliance fostered}

Even though the women had not made visible income they had begun to be independent as evidenced by them referring to future plans without quoting husbands or anybody such as government to do it for them. For example, one group revealed their plan to start a service station in future. They were already assessing their community needs. Another group which was not sponsored but got the training revealed how they had gone to the community leader to request a plot next to the river because the land they were using for their garden was dry. This request was considered and they had already moved. This group highlighted the need to have pamphlets to hand out to other women, as they were already going around teaching other women what they had learned. They felt that pamphlets "will help convince the women of what we are telling them".

\section{Charity fostered}

Though the groups were only engaged in survival economy, they still considered the needy members of their communities, for example, a woman in one group shared with her neighbours what she had in the garden. Another group focused on charity as one of the objectives of their small business project. "We would sell at the market and then give to the needy especially those affected with HIV/AIDS".

\section{Husbands more \\ accommodating}

The women reported that their husbands had become more accommodating about them going out to attend the meetings, including their church meetings which they had previously found difficult to attend. However, it seems the husbands were accommodating them due to their potential gain, as identified in group meetings and activities, rather than because of an enhanced awareness of women's rights. Two groups had male members in them, who may have joined because of unemployment and/or from the evident benefit received by the groups. A young male in one of the groups said: "I saw these ambitious women as good models for the community, and I decided to join them. I do not regret this today because we now have our own youth branch, and we are opening our own day care centre through a different sponsor who we obtained from Johannesburg. Some of the youth have gone to receive training for the day care centre as I speak'.

\section{Realisation of own rights}

Attending meetings at the clinics since the project started, as women acting in their own capacity were taken as evidence of a realisation of their rights. This right has extended to attendance at church meetings which are sometimes held at night, "as long as you come back home and fulfil your duties as a woman". Asking how they softened their husbands on this issue, the women said that they reported to their husbands what they had learned as a result of the project, and also that these men had heard by means of the political changes that women must be liberated. "They must stop sticking to the old customs of their great-grand-parents. They decided that they must leave us and see what we are going to gain from these meetings".

They all agreed, however, that they do not rule their lives. They claimed that they are bound by the rules of their marriages, which say that they must be subject to their husbands. "He (the husband) is the head of the family, you have to ask him about whatever you want to do. If your husband has parents, he is still subject to his parents. He cannot do anything without them". At home, a suggestion or an idea from them (women) was usually not considered. "There is still that oppression that reminds you that you are a woman, even if what you are suggesting is going to work. They (husbands) realise late when things have gone wrong that you were right. If you, as a couple, do not agree on some issue and even fight, and he beats you, the matter is taken to his parents". 
The women attributed the slow progress in attaining their rights to the patriarchal system. The person who most deprived them of their rights, in all groups, was the mother-in-law, who could even overrule decisions they had made jointly with their husbands.

Three groups of women also quoted the bible which says they (women) must respect their husbands, and that the husbands must love their wives. The women, however, felt that they behaved differently; they were mature, they didn't argue with their husbands any longer, but waited until they had calmed down. The husbands even commented: "This church of yours matures you, so you can attend". Sermons in church were often relevant to their situations/problems and they often shared the verses with their husbands who did not often attend, but were more accommodating about their attendance.

References to the husbands beating their wives, kept coming up during the interviews, in all the groups of women. They would refer to this as if it was not abnormal. This implied that women were still beaten, and that they were not of equal status with their husbands. Domination by a young male at an interview with one group of women was a clear demonstration of the submissiveness of women. The young male kept on answering the questions until the researcher prompted the women to talk. Another possibility could have been that the women or the young male, wanted to impress the researcher about having extended the project to the youth.

In conclusion the researcher posed the question as to whether, if a woman wants something she always has to ask permission from her husband. Women: "If you do not bow, you end up not getting what you want" In response to the question "what did you learn in the project?", the answer was, "We were taught to claim our rights but not by force. We were taught to communicate effectively".

\section{Conclusions drawn from the findings}

These conclusions will be discussed according to the power issues referred to under objectives, namely, powersharing in families, communities and other institutions, communication within families and communities, claiming of human rights, self-reliance and support services.

Women in the rural areas are traditionally seen as those members of the family who should stay at home and look after the family, while their husbands go to the cities for work. However, when it comes to economic and political decision-making, their husbands take the lead (Kongolo \& Bamgose, 2002:81). Power-sharing in families, communities and other institutions demonstrated some improvement in areas, particularly within the community as manifested in economic (business skills), social (catharsis) and health advice (HIV/AIDS and First Aid) within and outside the groups. This achievement compares with Blumberg's (2005:2) assertion that empowerment; economic in particular, may possibly reduce the rate of HIV/AIDS. Males and youth groups which joined two women's groups must have regarded the women as a source of income, and therefore felt that power could be shared with them.

Communication within the families and communities was greatly enhanced through the empowerment projects. Those women involved in the empowerment project found that their communication skills improved, which enabled them to engage with both the community and their families, predominantly their husbands. Through more effective communication with their husbands, the women had seen some softening of the male stance to their attendance of church and group meetings. They reported that this had been achieved by telling their husbands what they had learnt through the project. This demonstrates a great improvement from the baseline report on women saying, "My main problem is that I don't have an opportunity to communicate with my husband. If I am trying my utmost to create this opportunity he becomes irritable, saying that now I want to be the man in the family. But (sic) when something bad occurs within the family, I'm to be blamed to the extent of being physically abused" (Uys, \& Majumdar 2000:13). The most significant result of the empowerment was the establishment of a partnership relationship be- tween the groups and the primary health care nurses, evident in their sharing of resources for group activities such as the empty clinic rooms and land, and the reciprocation thereof by women's groups in assisting with clinic activities within their capabilities. Sharing the fresh produce with some needy members of the communities is also seen to have improved relationships.

Phillip and Bhargava, as cited in Uys and Majumdar (2000:6), propose individual, interpersonal, organisational and political indicators of empowerment. Using these indicators in the context of communication, it is apparent that the women who participated in the project had been empowered to a certain extent, and through their newfound skills they could continue to build on this.

Uys and Mujumdar's study (2000:21) highlighted the fact that women, very often, did not know their rights, and that, if they did, they often felt that they were not adequately empowered to access those rights. A study done by Sosibo (1999:5) found that women believed that the preservation of the Zulu tradition was empowering, but on the other hand, the leaders of the programme believed that modernising women was the best way of empowering them, and so taught them about their rights. The women acknowledged their attitude change as a result of the knowledge they had acquired with regard to their rights (Sosibo, 1999:5). Sosibo (1999:5) also reported that some women did not believe in the existence of women's rights. The current evaluation of the empowerment project reported that women identified certain activities, such as attending meetings, as a realisation of their rights. They attributed the softening of their husbands' attitudes, as mentioned earlier, to the fact that they reported back on what they had learned, and that their husbands had heard through the politicians that women must be liberated. However, this study highlighted the fact that the realisation of these rights is very limited within families, and that culture was the most likely reason for this. The women cited the mother-inlaw as being the main culprit hindering the acquisition of their rights. These women seemed to exercise their rights better within the communities than 
within families, as demonstrated by their claiming of user-friendly land, and correcting the attitude towards an HIV/ AIDS sufferer in one family.

Uys and Majumdar (2000:15) maintain that women believed that having a job was empowering, but that in a lot of instances the men did not want the women to work. Unemployment is a burden that many South Africans face, but this is very much more evident in rural areas. As a result of women's exclusion from many formal economic activities they have become involved in casual or unregulated labour as a means of coping with economic hardship (Oberhauser, 1998:1). Moreover, many rural women utilise collectives to generate income which in turn empowers these women (Oberhauser, 1998:1). A study by McIntosh, as quoted by Oberhauser (1998:5) showed that rural women had, through collectives, a greater chance of economic empowerment. The current gains were, however, used immediately for basic needs, and could not be invested, as also asserted by Kgatshe and Van Rooyen (2005 :iv).

This scenario was evident in this study; even those women who were not sponsored through the empowerment project had started projects which helped them survive. The study described women becoming independent/ self-reliant as a result of their incomegenerating activities which also enabled them to plan bigger projects for the future. Sosibo (1999:2) reported that income generation enabled the women to provide for their families. It changed the economic status of some, and made them self-sufficient, while for others, it supplemented what they received from their husbands, and freed them from their dependency on men.

These income-generating initiatives were empowering for women as evidenced by Phillip and Bhargava's indicators of empowerment cited in Uys and Majumder 2000: 15) - a sense of power was felt by these women, that they were able to affect the lives of others, that through their groups, they were able to empower others, and that they were able to work with others to change social institutions. Despite the fact that they were only engaged in a survival economy, these women still considered the needy in their commu- nities.

Self-confidence and self-reliance as indicators of inner transformation of one's consciousness can enable one to overcome external barriers to accessing resources. Herrick (1995:1) asserts that empowerment also includes the right and responsibility to participation in creating resources and eliminating inappropriate or ineffective resources, as the rural women did in one clinic where the land was too dry to grow their fresh produce. Blumberg (2005:3), on the other hand, contends that selfconfidence which accompanies empowerment helps women obtain 'voice and vote' in household decisions such as domestic wellbeing, economic, fertility, land use and conservation.

The strong relationship between the women's groups and the primary health care nurses revealed their awareness and their ability to utilise nurses as their support service for empowerment. The women's groups also used the groups themselves as a support service for catharsis/abreaction especially for family problems, including those of the extended family. The groups referred to the option of referral for some problems, especially health problems, indicating an awareness of the availability of outside support in case of failure to help themselves. The use of external funding other than that of the project by one group for their youth project, revealed that the women's groups could utilise support services for empowerment. Dugan (2003:3) supports the notion of support services through networking with others both inside and outside their own social groups. Networking helps share group activities, successes, failures and solutions, whatever resources, contacts or information they have access to and which others may probably need. While external change agents can catalyse the process of empowerment, or create a supportive environment, the people ultimately empower themselves (Sen, 1997:6)

\section{Recommendations}

The researcher recommends strategies for empowerment of the disadvantaged and oppressed cited by Dugan (2003:2), for example:

Education for empowerment cited in
Paulo Freire's "Pedagogy of the Oppressed" which considers the fact that the disempowered already know about the sources of their problems and the possible solutions, but just need an organised approach to these solutions. This approach is aligned with the transformative learning theory in which participants learn to negotiate and act on their own purpose, values, feelings, and meanings, rather than those imposed on them (Mezirow, 2000, cited in Dugan 2003:2). Therefore, it is imperative to assess the strengths and weaknesses of these groups to be able to build on the strengths and act on the weaknesses, according to whether they are in control or not. If not in control, external support must be sought by the groups themselves.

\section{Organisation}

Dugan (2003:3) asserts that an organisation gives people the power to express their needs effectively without being ignored. Such groups can start small until community-wide organisations are formed.

\section{Networking}

Affiliation to groups allows the disempowered to network with others, both inside and outside their own social groups, thereby realising and extending power. The small groups could affiliate themselves with umbrella groups or campaigns such as, Proudly South African for financial and technical support (Proudly South African, 2001:1).

The project executive also recommended that The Provincial Department of Health could take the project further, as its early involvement as a partner was solely for the sustainability of the project.

\section{Limitations of the Study}

Data collection was self-reporting and, as such, the credibility of self-reports could be challenged, especially with an internal evaluation of the project.

The experimental and control groups were not accurately aligned, as explained earlier, because the groups were at different stages of development in their projects, as one of the criteria was whether they were engaged in funded projects or not. 


\section{Summary}

The project of rural women's empowerment under study has revealed an improvement in the women's realisation of their rights, albeit limited, communication, self-confidence and reliance, including relationship/partnership between Primary Health Care Nurses and women's groups. Recommendations have been made towards education for empowerment, which is transformative, and organisation of the disempowered into groups, thereby enabling them to network within and outside the groups for financial and technical support.

\section{Acknowledgements}

The Canadian International Development Agency for funding the project, Project Team: Prof LR Uys and Prof B Majumdar, Dr GG Mchunu and Ms JR Naidoo.

\section{References}

AKINSOLA, HA \& POPOVICH, JM 2002: The quality of life of families of female-headed households in Botswana: A secondary analysis of case studies. Health Care for Women International.23: pp761-772.

BLUMBERG, RL 2005: Women's Economic Empowerment as the "Magic Potion" of development. Presented paper at the $100^{\text {th }}$ Annual Meeting of the American Sociological Association, Philadelphia:

Online: http://portal.unesco.org/shs/ en/ev.php-URL-ID=8696.8URL$\mathrm{DO}=\mathrm{DO}-\mathrm{PRINTPAGE \& URL}$ SECTION=201.html Retrieved on 15/10/ 2007.

BOHLER_MULLER, N \& DANIELS, B 2009: Does the CXommunal Land Rights Act Really Protect the Rights of Rural Women to own Land? Afrigrowth Agenda. April- June 2009.

BRIDGE 2001: South Africa: Discrimination against women persists. University of Sussex, Institute of development studies report (Brief article), Win News.

\section{COMMISSIONONGENDEREQUAL} ITY-SOUTHAFRICA 2009:

Online: file://E: $/$ Commisssion on Gender Equality - SouthAfrica_onfo.htm retrieved on 6/19/2010.
CRESSWELL, JW (2009): Research Design: Qualitative, Quantitative, and Mixed Methods Approaches $3^{\text {rd }}$ ed. Los Angelos: Sage

DUGAN, MA 2003: Beyond Intractability: One View of Empowerment.

Online: www beyondintractability,org/ essav/empowerment/ Retrieved on 10/ 10/2007

DU PLESSIS, H 2007: United in our diversity: Working together towards the total emancipation of Rural women from poverty and hunger. $4^{\text {th }}$ World Congress of Rural Women, 23-25 April 2007, South Africa: Durban, UBISI MAll June: pp4-5.

GILLWALD, C 2002: Access to justice a vital contribution to the empowerment of women. Online: http:ll www.doi.gov.za/m speeches/sp2002/ 200208 30 htm Retrieved 20/10/2004.

HERRICK, J 1995: Empowerment practice and social change: The place for New Social Movement Theory. New Social Movement Network.

Online:http://www.interweb-tech.com/ nsmnet/dcos/herrick.htm Retrieved on 10/10/2007.

KACHINGWE, N 2001: Africa: Women are loosing the battle of education: reports from around the world: Africa Win News.

KGATSHE \&VAN ROOYEN 2005: Livelihood activities in Female-Headed Households: Letlakane Village. Abstract: Masters Dissertation. Johannesburg: University of Johannesburg: Department of Anthropology and Development studies.

KONGOLO, M \& BAMGOSE, OO 2002: Participation of rural women in development: A case study of Tsheseng, Thintwa, and Makhalaneng villages, South Africa. Joumal of International Women's Studies, 4(1):pp79 92.

LOCKE, LM 1999: Attitudes towards domestic violence: race and gender issues. Sex Roles: Journal of Research February 1999:

Online: htto://www.findarticles.com/ cf $0 / \mathrm{m} 2294 / 3-4 \quad 40 / 54710014 /$ nrint/ ihtml Retrieved 19/06/2002
MOGOTLANE, SM \& UYS, LR 2000: The functions and impact of women's organisations on community development and rural Primary Health Care. Curationis 23(1): pp19-24.

MACKIAN, SC 2008: What the papers say: reading therapeutic landscapes of women's health and empowerment in Uganda. Health and Place 14:pp 106115 .

MURPHY-GRAHAM, E 2010: And when she comes home? Education and women's empowerment in intimate relationships International Journal of Educational Development 30: pp 320331.

OBBO, C 1981: African Women: Their struggle for economic independence. Johannesburg: Ravan Press.

OBERHAUSER,AM 1998: Gendered livelihood strategies in rural South Africa and Appalachia. Annual meeting of the South Eastern Division of the Association of American Geographers. Memphis, Tennessee.

OLATOKUN,WM \&AYANBODE,OF 2008: Agriculture and Food Production: Use of Indigenous knowledge by Rural Women in the Development of Ogun State. Indilinga-African iournal of Indigenous knowledge Systems 7(1): pp47-63.

PINI, B 2002: Focus Groups, feminist research and farm women: opportunities for empowerment in rural social research. Journal of Rural_Studies 18: pp339-351

PROUDLY SOUTHAFRICAN 2001: Online:http://www.proudlysa.co.za/ $a b \quad 0 \quad u t / p r / 2001 /$ prl114.html.Retrieved:10/09/2004.

READER, DH 1966: Zulu Tribe in Transition: The Makhanya of Southern Natal. London: Manchester University Press.

REPUBLIC OF SOUTHAFRICA: The Constitution, Act no 108 of 1996. Pretoria: Constitutional Assembly.

SEN, G 1997: Empowerment as an approach to poverty.

Online: http://www.grhf.harvard.edu/ 
2007.

SOSIBO, Z. 1999: Empowerment of rural Zulu women through popular adult education in South Africa: A case study of the National Association for Womens Empowerment (NAWE) Programme in KwaZulu-Natal.

Online: http://wwweedst.educ.ubc.ca/ aerc/1999/99sosibohtm Retrieved on 15/10/2007.

SPEZIALE, HJS \& CARPENTER, DR 2007: Qualitative Research in Nursing: Advancing the Humanistic Imperative. ( $4^{\text {th }}$ ed). Philadelphia: Lippincott Williams \& Wilkins: a Wolters Kluwer Business.

UYS, LR \& MAJUMDAR, B 2000: An analysis of the level of empowerment of rural women in KwaZulu-Natal, South Africa. Unpublished manuscript, Durban: School of Nursing, University of Natal.

VAN DER MERWE AS 1996: An Epistemological study of the power as nurses- a phenomenological approach. $\mathrm{PhD}$ thesis. Durban: University of $\mathrm{Na}-$ tal.

VLASOFF, C 2001: Women's empowerment. Paper presented in Delhi. India at a conference: Women's status: vision and reality. Online: file://E:INational Policy for the empowerment of women.htm Retrieved on 19/06/2010.

WAITE, L 2000: How is Household Vulnerability Gendered? FemaleHeaded Households in the collectives of Suleimaniyah, Iraqi Kurdistan. Disasters 24(2) pp153-172. 